\title{
Siege Memory - Besieged Memory? Heroism and Suffering in St Petersburg Museums dedicated to the Siege of Leningrad
}

\author{
Yvonne Pörzgen*
}

\begin{abstract}
The official Soviet narrative of the Second World War used the concept of heroism to imbue war commemoration with an obligation towards the state. Such a concept was designed to make subsequent generations feel inferior to their predecessors and obliged to give of their best. Today, the victory serves as the strongest connection between Soviet and modern Russian patriotism.
\end{abstract}

The paper argues that the memory of the Siege of Leningrad (1941-1944) as treated in museums in St Petersburg today is an appropriation by present-day Russian propaganda of the Soviet narrative. Soviet memorial sites are developed to foster support for Russia rather than the former Soviet Union. While the use of the heroic paradigm continues, the definition of heroism has changed to include each and everybody who suffered during the Siege. With collective heroism as the leading image, a critical view of the historic events becomes all but impossible. The paper makes references to the alternative narratives of literature, memoirs and diaries to contrast the version of the Siege presented in the museum exhibitions.

Key words: War Museums, Siege Commemoration, Victimization, Diaries, Russia, Siege, Great Patriotic War

\section{Welcome to the City of Heroes}

When travelling to St Petersburg and taking a taxi or a "marshrutka" (a taxi-bus) from the airport to the city centre, visitors pass a conspicuous stele. The monument was built in 2005 and consists of a monumental Greek-style column and the inscription "Saint Petersburg, Leningrad, Hero City" (Sankt-Peterburg, Leningrad, gorod geroy). ${ }^{1}$ The lettering refers on the one hand to the continuity with the city's tsarist past when it was founded by Peter the Great and given the name "Saint Petersburg". After a referendum in 1991, "Saint Petersburg" was re-established as the city's name. On the other hand, the stele links the city with the Leningrad of the Second World War or rather, as it is called in Soviet and now Russian historiography, the Great Patriotic War (1941-1945).

The city proudly highlights its Soviet title of Hero City. The adjective "heroic" almost always appears when the war, and especially the period of the Leningrad Siege (8 September 1941 - 27 January 1944), is mentioned. The concept of heroism is the defining principle of museum exhibitions dedicated to the Siege, thus strictly dividing what can be shown from what has to be left out.

The idea of the heroic population of Leningrad drives the permanent exhibitions that are displayed today. One may assume that the link with heroism evokes an emotional reaction of awe, veneration or even adoration. Heroes are not to be criticized. By declaring that all members of the Leningrad population affected by the Siege were heroes, the museums block any critical approach to the Siege events and the actions of state and city leaders and impose an obligatory element of self-sacrifice onto every form of suffering and dying. The museums tell the same story as do TV and cinema productions. Alternatives to this official narrative can be found in media with a smaller distribution range, mostly in published diaries and scholarly publications based on archival research. 


\section{Emotions in research and museum practice}

The term "emotion" covers a wide field of concepts. In etymological definitions, emotions are inner movements that find outer expression. Emotions in the form of feelings are mental or bodily reactions. Emotional reactions can be spontaneous. People may try to control or to hide their emotions. As the neuropsychologist Antonio Damasio (2000) has shown, emotions are not the Other of rational thinking. Rationality and emotions are inseparable and form an integral part of a person's perception and interpretation.

Emotions, as part of the inner human life, are experienced by everyone. In the system of social exchange, people register other people's emotions. We can understand and deduce somebody else's emotions by taking in their body language, facial expressions, voice etc. Thus, emotions play a dual role of internal and external information (Müller and Reisenzein 2013: 25).

Sharing emotions appears to work easier than sharing knowledge and understanding. The sociologist and philosopher Max Scheler called this phenomenon "emotional contagion" (emotionale Ansteckung) (Scheler 1923: 25). Collectives have developed amplifying and resonance mechanisms for emotions (Ciompi and Endert 2011: 16). Media can function as such catalysts of collective emotions (Schnabel 2015: 34). Museums can function this way as well through their role as places where learning happens. As studies on the functions of memory have shown, learning works best when the learner is in an emotional relation to the object in focus. Museums are also places of experience. Emotions manifest themselves in the way we experience impressions, activities and sensations. Emotions regulate perception and attention, they influence thinking and memory. As reactions to outer stimuli, emotions can easily be influenced (Ciompi and Endert 2011: 13 resp. 222). Museums are spaces designed for communication, thus the involvement of emotions is inevitable.

The connection between museums and emotions is most obvious in museums that are explicitly dedicated to emotions like the New York exhibition Museum of Feelings (01-14 December 2015). Its installations invited visitors to an emotional interaction which in turn caused environmental changes, such as the colours of the lighting. ${ }^{2}$

The Saint Petersburg Muzej emotsij was founded by the "Russian Warhol", Aleksey Sergienko, and opened in 2016. It challenges its visitors to react with positive or negative emotions to its exhibits. Sensory stimulations provoke reactions of happiness, disgust, fear etc. (Holm 2016a).

The difference between these projects and the emotional effect of historical exhibitions is the prominence of the emotions. While the Muzejemotsijexpressly states that it provokes certain emotions, historical exhibitions do not stress their emotional effect, although their conceptions aim at no weaker emotional reactions. The image of the hero that features prominently in St Petersburg Siege museums evokes strong emotional reactions.

\section{Definitions: Heroism}

According to the specialists in German studies, Nikolas Immer and Mareen van Marwyck, the images of heroes always have concrete social and political functions. They give physical, psychic or ethical orientation by showing the extremes of what can be reached by mankind. For modernity, Immer and van Marwyck see heroes as a compensation for a reality that is perceived as mostly a-heroic. At the same time, they do not define a special heroic phenotype but state that shifts have occurred. While the heroes of antiquity were seen as exaggerated versions of humans turned godly, the modern hero has undergone a process of differentiation (Immer and van Marwyck 2013: 11-15). The historian René Schilling differentiates between "Opferheld", the hero who sacrifices himself, and "Führerheld", the heroic leader, as the two types of war heroes (Schilling 2002: 25-26).

In art, this understanding of individual heroism as personified in heroic leaders can be seen for example, in the works of Georg Baselitz from the years 1965/66. The paintings are called "Rebel", "A New Type", "The Modern Painter" or "The Shepherd". Since there are at least 70 of these hero paintings, the heroes lose part of their individual achievement and form an army of their own (Voss 2016).

The catalogue to the exhibition Heroes. On the longing for something special (Helden: von der Sehnsucht nach dem Besonderen), held at in the Westfalian Museum of Industrial 
Culture in 2010, lists different kinds of heroes: the heroes of antique myths, heroes of the middle ages armed with cross and sword, national heroes, sports heroes, socialist heroes of labour and the heroes of modern mass media. In her contribution to the catalogue, the historian Ute Frevert adds the "heroes of everyday life", also calling them "silent heroes":

People like you and me act in an unusually visible, active way and thus do good or keep something bad from happening. They do not always take a personal risk: endangering their life doubtlessly makes the deed more remarkable, but it is not a prerequisite of heroism. But what turns out to be the smallest factor in common is the engagement for somebody else, be it people in distress or freezing cats.

Menschen wie du und ich handeln in außergewöhnlich präsenter, zupackender Weise und tun damit Gutes oder verhindern Schlechtes. Längst nicht immer gehen sie dabei ein persönliches Risiko ein: Gefahr für Leib und Leben macht die Tat zweifellos bemerkenswerter, ist aber nicht zwingend, um Heldentum zu besiegeln. Was sich hingegen als kleinster gemeinsamer Nenner herausschält, ist der Einsatz für andere, seien es Menschen in Not oder unterkühlte Katzen. (Frevert 2010: 13)

Thus, everybody can become a hero. But not everybody is up to the task.

In 2016, a German-Polish conflict evolved around the commemoration of Poles who protected Jews during the Second World War. The German historian and journalist Joseph Croitoru criticized the Polish emphasis on the heroism of such Poles as they were the exception rather than the rule. In response Łukasz Kamiński, president of the Polish Institute for National Memory, argued that heroic deeds are never typical (Kamiński 2016).

The occurrence of the silent hero can be interpreted as an effect of the postheroic society the politologist Herfried Münkler sees in the West. In Münkler's definition, heroism is unthinkable without a vivid religious or ideological anchor in society. Due to a lack of such a binding idea that is generally agreed to be worth dying for, the Western world, Münkler claims, has transgressed into a postheroic state (Münkler 2007). Contemporary Western postheroism stands in harsh contrast to the communist hero cult that was prominent in all Eastern block countries.

The Great Soviet Encyclopedia (3rd edition 1969-1978) defines heroism as a quality that is mostly found in socialist societies. Soviet heroism is defined as mass phenomenon:

Heroism, heroic, the achievement of deeds outstanding in their social relevance, corresponding to the interests of the masses and the progressive classes, demanding personal courage, perseverance, readiness and self-sacrifice.

Героизм, героическое, свершение выдающихся по своему общественному значению действий, отвечающих интересам народных масс, передовых классов и требующих от человека личного мужества, стойкости, готовности к самопожертвованию. ${ }^{3}$

The heroic mass is defined as a necessary precondition for the victory of socialist evolution. In contrast to all other definitions that see the individual achievement of a person as prerequisite for a hero, the Soviet definition of heroism stresses the role of the masses and makes heroism a mass achievement rather than an individual deed. The individuals sacrifice their lives for the good of the masses.

After the War, the Soviet Union instrumentalized heroism in a two-fold manner, as the historian Andrea Zemskov-Züge shows. The topos of heroism was used to imbue war commemoration with an obligation towards the state. The following generations were to feel inferior to their predecessors and obliged to give their best. In this stereotypical depiction of heroism, Zemskov-Züge notices a negative relation of effort and result. High risk was enough proof of heroism, and the actual achievement was of less importance (Zemskov-Züge 2011: 143). In this respect, the Soviet definition of heroism differs from Frevert's explanations of the silent or everyday hero who does not necessarily risk his or her life in achieving something remarkable. 
The victory in the Great Patriotic War serves as the strongest connection between Soviet and modern Russian patriotism. The social decline of Russian society after the collapse of the Soviet Union led to disorientation and a loss of identity. As a consequence, in 1996 the Russian president, Boris Yeltsin, organized a competition and asked participants to define the new national idea. The results showed the longing for old patriotic ideals. Instead of new ideas, Russia implemented ceremonies and festivities linking it to eclectic events and symbols of the Tsarist and the Soviet past (Scherrer 2002: 179). The historians Beate Fieseler and Jörg Ganzenmüller quote the result of a 2005 opinion poll in which $60 \%$ of the people answered that the festivities on 9 May, Victory Day, had filled them with pride (Fieseler and Ganzenmüller 2010: 7). The relevance of Victory Day has even grown over the past few years, and the festivities have become more and more pompous. Russians adorn their cars with stickers saying "thank you, granddad, for the Victory" (spasibo dedu za pobedu), and similar slogans are printed on posters.

The Leningrad Siege took place during the Great Patriotic War, but it forced the political and military leaders as well as the general population of the besieged city to develop survival mechanisms without relying on the national leadership in Moscow. But the official commemoration today does not differentiate between Siege heroism and War heroism.

In the presence of heroism, people are to feel respect for the heroic deed. They are supposed to be in awe of the heroic deed and to accept the hero as a model, an ideal to emulate. On the other hand, there is the idea of the everyday hero, the silent hero, ordinary people who have mastered a challenge. Both types of heroes are found in relation to the Leningrad Siege, but the museum exhibitions do not differentiate or explain what they label as heroic. Civilian suffering as well as military achievements and self-sacrifice are summed up as "collective heroism" in the museum exhibitions which creates the impression of a purpose of suffering and death that was not necessarily present at the time.

\section{The Leningrad Siege}

On 22 June 1941 Nazi-German troops attacked the Soviet Union and started operation 'Barbarossa'. Part of the plan was to occupy and destroy Leningrad as quickly as possible. To defend themselves, until October 1941, 300,000 Leningraders were recruited into the Red Army, and 200,000 volunteered for the home guard. Teenagers, pensioners and women were called to the factories to replace the men (Kirschenbaum 2006: 43). About 500,000 citizens, mostly young women, were recruited during the summer to dig tank defense trenches and build fortifications. Their working in the unprotected open made them especially vulnerable to Nazi-German air raids.

In Leningrad and Moscow, food rationing was introduced in mid-July (Bidlack 2005: xiv). 6 September 1941 saw the first large-scale bombardment of Leningrad. On 8 September 1941 the city was cut off from any land connections to the so-called "main land" (bolshaya zemlya). The German command abandoned the plan to destroy the city in favour of besieging and starving it to death. Food supplies in the city were scarce. Hunger set in almost immediately. During the first siege winter the death tolls were especially high.

There were five categories of rations: for workers in hot shops, other workers, office workers, dependents and children under 12. The daily bread rations of an office worker were:

18 July 1941: 600 grams

2 September 1941: 400 grams

12 September 1941: 300 grams

1 October 1941: 200 grams

13 November 1941: 150 grams

10 December 1941: 125 grams

25 December 1941: 200 grams 


\section{January 1942: 300 grams}

11 February 1942: 400 grams

\section{March 1942: 500 grams}

Dmitry V. Pavlov, representative of the city defense committee for the provision of Leningrad from 1941 to 1942, published a report of the Siege in 1958 and described the poor quality of the already too small bread rations. The scarce flour was stretched with substances like cellulose; of little, if any, nutritional value (Pavlov 1958).

The road over the frozen lake Ladoga became the most important, but highly dangerous, supply line and evacuation road of the city. In January 1943, the Red Army managed to free a stretch of land on the lake border. Rail tracks were built to increase the city's food and goods supply. On 27 January 1944, the siege ring was finally broken through, and the siege was over (for a detailed analysis of the Siege events, see Reid 2011).

\section{Research on the Siege}

Ganzenmüller calls the Siege one of the largest catastrophes of the Second World War (Ganzenmüller 2005: 1). Documentation of the Siege started while it was still going on. This is an aspect the Siege museums have in common with the Imperial War Museum London which was founded in 1917 during the First World War. The impulse was the recognition of the moment's historical dimension (Schoder 2014: 52). From 1941 to 1946, the Leningrad Institute for Party History collected eye-witness reports and diaries, and organized events where Siege survivors were encouraged to report their Siege experiences (Zemskov-Züge 2012: 139). In Soviet times, large parts of this material were not accessible. Perestroyka, the collapse of the Soviet Union, and the opening of archives and libraries for international research, brought forth the publication of formerly unknown reports, memoirs and diaries ${ }^{4}$ In addition to these documents, personal letters written during the Siege were found in (museum) archives, e.g. letters written by artists (Suris 1993). In (Western) Germany, these documents served to include the Leningrad Siege into the discourse on National Socialist war crimes (Jäniche and Leetz 1992).

Research on the Siege is manifold and focuses on many special aspects. In Saint Petersburg, individual institutions published studies on their history during the Siege, e.g. the State University (M. Śiśkin 1996). In a continuation of Granin's and Adamovich's first steps in oral Siege history in the 1980s (see below), the European University of Saint Petersburg founded the Oral History Centre, and in 2001-2003 conducted studies on the Siege: The Siege in the fates and memories of Leningraders (2001-2003) and The Siege in individual and collective memory of the City's citizens (Loskutova 2006). Siege research covers many areas. Aileen Rambow analyzes the connections between literature and ideology during the Siege (Rambow 1995). Andrey Dzeniskevich, in 2002, presented a monograph on the medical research conducted during the Siege. The hardships people, especially children, had to endure are the topic of studies by Tamara Staleva and Lisa Kirschenbaum (Staleva 1995; Kirschenbaum 2002). ${ }^{5}$

In spite of the manifold lines of research, some stereotypes are hardly touched upon, neither by researchers in Russia nor in other countries. For the 1990s, the Russian historian Andrey Dzeniskevich identifies the problem in the continuation of the Soviet cult of heroism that makes it impossible to ask questions which might raise any doubt in the heroic achievement of the city (Dzeniskevič 1998: 46-48). This problem continues to exist. In the words of Andrea Zemskov-Züge:

Also western authors partly avoid a critical assessment of the hero paradigm. This attitude of avoidance, in my opinion, is the reason that up to now, important topics such as political persecution or misappropriation of food by party officials have not been researched systematically.

Auch westlicheAutoren meiden teilweise eine kritische Auseinandersetzung mit dem Heldenparadigma. Diese Vermeidungshaltung führt meines Erachtens auch dazu, 
dass wichtige Themen wie politische Verfolgung oder Lebensmittelunterschlagung durch Parteieliten bisher nicht systematisch untersucht wurden. (Zemskov-Züge 2012: 40)

Zemskov-Züge criticizes scholars like Vitaly Kovalchuk (Koval'čuk 2003: 543) for perpetuating the image of mass heroism. The use of this term glosses over situations of sheer hopelessness (Zemskov-Züge 2012: 30). This paper sheds light on the mentioned hero paradigm and shows its perpetuation in today's museum exhibitions, but also alternative narrations that can be found in published diaries and memoirs.

\section{Heroism and the Siege: Soviet titles and monuments}

As early as 1 May 1945, Leningrad received the title of gorod-Geroy (Hero-City) and was one of 12 cities (plus the hero-fortress of Brest) to be honored in that way. Leningrad, Stalingrad, Sevastopol and Odessa received the title according to Order No 20 by Stalin in his function as Commander in Chief, 1 May 1945. The decision was confirmed and the title also given to a number of other cities in 1965 by the Presidium of the Highest Soviet of the Soviet Union. In 1980, the text of the decision was slightly altered. The first paragraph then started:

1. As highest grade of distinction, the title "Hero City" is awarded to cities in the Soviet Union whose working population showed mass heroism and bravery in the defense of their home country during the Great Patriotic war, 1941-1945.

1. Высшая степень отличия - звание «Город-Герой» присваивается городам Советского Союза, трудящиеся которых проявили массовый героизм и мужество в защите Родины в Великой Отечественной войне 1941-1945 гг. ${ }^{6}$

The Great Soviet Encyclopedia defines Hero City as "title of honor given to Soviet cities that excelled in their heroic defense during the Great Patriotic War" (pochotnoye zvanie, kotorogo udostoeny goroda SSSR [...] proslavivshiesya svoyey geroich. oboronoy v period Velikoy Otechestvennoy voyny 1941-1945)..$^{7}$ Leningrad was one among others, the Siege was not to be seen as a single event, it was not even mentioned. The title was received to honor the defense, not the survivors.

In the period of the heroification of the Great Patriotic War under Khrushev in the 1960s, it was the lifting of the Siege as the result of the heroic military defense that was concentrated upon. This attitude can be seen in the memorial for the heroic defenders of Leningrad, erected in 1975. From below, you see the victors, the soldier and the worker, in front of a monumental obelisk. In accordance with Socialist Realism, this couple appears like a sombre quotation of the famous sculpture Worker and Kolkhosnitsa in its monumental dimensions and by forcing the viewer to observe it from below.

The war-time propaganda in Leningrad was the origin of the depiction of civic heroism. As Lisa Kirschenbaum notes:

The media both encouraged Leningraders to see themselves as connected to others in "purposeful action" and facilitated such connections.

Moreover, the media's contention that Leningraders were not passive victims but active defenders may well have matched Leningraders' own sense of the momentousness and importance of their experiences. [...] The notion that Leningraders, even as they starved, were somehow fighting on the city front answered the burning and terrible question, "What was the point?" It offered a useful truth, a meaningful struggle. (Kirschenbaum 2006: 53-54)

The war in general and the Leningrad Siege especially were received as "history in the making" (Kirschenbaum 2006: 77). Already in December 1942, there was an exhibition on The Komsomol in the Fatherland War, displaying photographs, diaries, letters and blood-soaked Komsomol 
cards (Kirschenbaum 2006: 77-78; quotes Komsomolskaya Pravda, 20 December 1942).

Under Stalinism, commemorating the Siege was a critical undertaking. The 1949 socalled Leningrad Affair (Leningradskoye delo) was a process to discredit Leningrad elites who had been active during the Siege. They were accused of establishing a memory of the Siege as a single event whose ending was not connected well enough with the decisions taken in Moscow. The reason for the discrediting the Leningrad leaders is nowadays seen in Stalin's fear of competition. Due to the Siege situation, Leningrad in many respects was left to fight alone for itself. After the War, Stalin was critical about the level of independence in Leningrad's actions and so he was determined to eliminate any memory of events that were not immediately directed by Moscow. In February 1949, Popkov and Kapustin, the first and second secretary of the Leningrad Party organization, were discharged. Six high Party officials were executed in 1950. All in all, over 2,000 Party, Soviet, Komsomol and Union representatives were expelled between 1949 and 1952 (Zemskov-Züge 2012: 105). In the wake of the Leningrad Affair, the first Siege museum was closed. In public ceremonies and publications, the Siege was presented as a minor "place d'armes" of the heroic fight of the Soviet people against the Fascist invaders. Since 1991, the Siege as part of the Great Patriotic War (1941-1945) has become an integral element of Russian media life. Zemskov-Züge states:

Today the heroic myth is still the central interpretation grid of the "Great Patriotic War" in Russia's public commemoration.

Noch immer ist der Heldenmythos das zentrale Deutungsmuster des 'Großen Vaterländischen Krieges‘ im öffentlichen Gedenken Russlands. (Zemskov-Züge 2011: 136)

The historian Michael Melnikow, in analyzing Russian TV programmes, uses Jean Baudrillard's concept of the simulacrum, an image without an original, without reference to whatever may be understood as reality. Melnikow sees the simulacrum as a central principle for the analysis of Russian society and its media. Russian society is acting in a simulated reality. In his analysis of the documentary The Great War (Velikaya Voyna), produced in 2010 for Pervyj Kanal (First Channel, state TV), Melnikow singles out episode three of eight, dedicated to Leningrad. The Siege is not shown as an event of its own, but in the context of the Battle of Leningrad, reducing the suffering of the population to a mere illustration of the fight:

The suffering has no meaning of its own, it has to remain the background for a hero story.

Das Leid hat keine eigenständige Aussage, es muss Resonanzraum für eine Heldengeschichte bleiben. (Melnikow 2011: 335)

The same is true for the fiction film Leningrad, also called Attack on Leningrad (2007), a Russian-UK co-production. Asentimental story is told against the background of a kaleidoscope of clichés and fragmented history. Melnikow's final comment: is "It's about heroes and their fight" (es geht um Helden und deren Kampf; Melnikow 2011: 336). ${ }^{8}$ The heroic story of the Leningrad Siege has been turned into a conglomerate of clichés due to the necessity of relying on the heroic myth.

\section{Heroism in the siege museums}

The main sites of memory connected with the Siege are the Siege museums and the exhibitions in historical museums in St Petersburg. They differ in size, but not in their narrative. Therefore, the following analysis focuses on the two exhibitions with the longest tradition, the State Museum of the Defense and the Piskaryov Cemetery, for they can stand as examples for all Siege exhibitions in St Petersburg. It is true that other museums feature more modern exhibition techniques than the two chosen ones. One example is Tanya Savicheva's former school, where a classroom also features as Savicheva Museum. 
Tanya Savicheva's diary was one such document. Tanya (born 1930) recorded the death of one family member after another. The whole text reads:

Zhenya died on 28 December at 12 P.M. 1941

Grandma died on 25 January 3 P.M. 1942

Leka died on 17 March at 5 A.M. 1942

Uncle Vasya died 13 April at 2:00 after midnight 1942

Uncle Lesha 10 May at 4 P.M. 1942

Mother 13 May at 7:30 A.M. 1942

The Savichevs died.

Everyone died.

Only Tanya is left.

28 декабря 1941 года. Женя умерла в 12 часов утра.

Бабушка умерла 25 января 1942-го, в 3 часа дня.

Лёка умер 17 марта в 5 часов утра в 1942 г.

Дядя Вася умер 13 апреля в 2 часа ночи.

Дядя Лёша 10 мая в 4 часа дня.

Мама - 13 мая в 730 утра 1942 года.

Савичевы умерли.

Умерли все.

Осталась одна Таня. ${ }^{9}$

The diary was found when Tanya was evacuated. She died in 1944 from the consequences of the catastrophic Siege conditions. The original of the diary is on display in the Historical Museum of the City of St Petersburg, and copies are shown in the Piskaryov exhibition pavilion, the Tanya Savicheva School Museum and other museums. Tanya Savicheva and her diary have become indispensable for every Siege exhibition, like the Siege room and the bread ration. ${ }^{10}$ In the context of the Siege museums, Tanya's fate becomes an icon of martyrdom. In the Savicheva School Museum, visitors can leaf through Tanya's diary on a computer flatscreen. But the school room museum is used for the pupils' meetings with Russian army generals during the compulsory "bravery lessons" (uroki muzhestva). The use of technical devices does not alter the heroic narrative that perseveres in the more modern museums as it does in the museums chosen for this paper.

Understanding museums as a medium like texts and websites, it is the aim of this paper to analyze how the specific medium of museums conceives the construction of the siege hero. Historical museums can be seen as places of social history, in addition to the exhibition narrative they offer about a society's attitude to history and national identity (Bogumił 2015: 3 ). But they can also be (mis-)used as sites of propaganda where the visitors are instilled with an opportunistic attitude towards history and state. The Siege museums show aspects of both approaches. The city's main Siege museum is the State Museum of the Defense and the Siege of Leningrad. Already in 1942, an exhibition on the Siege and Defense of Leningrad had been set up. After the end of the Siege, it was changed, and reopened on 30 April 1944 under the name The Heroic Defense of Leningrad. On the second anniversary of the lifting of the Siege, the exhibition was reopened as a permanent museum. Stephen Maddox characterizes the exhibition's and later the museum's official version of the Siege as an invitation to relive the Siege's "heroism and tragedy" and "to take part in the ritualized performance" of Siege remembrance ${ }^{11}$ (Maddox 2008: 189-190). 
The Museum tried to stress Stalin's role in the endurance and lifting of the Siege (ZemskovZüge 2012: 250). Still, a 1948 assessment of the Museum stated that its characterization of Stalin's and the Party's impact on the victory of Leningrad was not sufficient. The Museum was closed for revision in 1949. As a consequence of the Leningrad Affair, it was liquidated in 1953. The Museum was re-founded in 1989. Anew permanent exhibition was launched in 2004.

The translator and journalist Susanne Brammerloh describes the Siege Museum as Soviet in style and presentation: the didactics are frontal, the tour guide does not report anything outside the regular framework of the official narrative (Brammerloh 2011: 351).

The Museum follows the naturalistic tradition on the one hand, making use of symbolism on the other. The exhibition plan is meant to recall the Siege situation, representing the military aspects of the Siege along the walls encircling the showcases embedded in stylized facades, representing the civil life in the besieged city. This structure supports the process of aesthetic identification (Jauß 1974).

In one of the niches dedicated to the life in the city, you find a so-called Siege room. It works as a collection of symbols. The sledge is to remind the visitor of the sledges used to transport corpses to the cemeteries. The radio is the visible reminder of the Leningrad radio station that sent transmissions almost all the time during the Siege and in the breaks listeners heard a metronome that was often mentioned in diaries. It came to symbolize the still-beating heart of the city. The museum guides switch on the sound of this metronome, followed by the sound of air-raids and sirens, for groups of visitors. They are shown a kettle, standing for the disrupted water ducts, forcing people to collect water in the streets or from the river. The home-made oil lamp on display refers to the power cuts. Central heating did not work either, so people bought or built small stoves, so-called burzhuiki. Of course, there is one in the reconstruction of a Siege room. Siege room reconstructions like this one are shown in at least ten museums in St Petersburg (Demidenko 2010: 73).

Another object also found in all museums dealing with the Siege is the smallest bread ration. Especially in the first Siege winter 1941/1942, the people in Leningrad starved and many died of starvation. Bread became the most important food, but since flour was extremely short, bread rations were lowered dramatically, reaching a mere 125 grams a day for office workers in December 1941. In this respect, the dire situation of Leningrad's inhabitants was similar to that of the Jews in the Warsaw ghetto in 1942. In his report on the ghetto, the historian and politician Władysław Bartoszewski cites a report from the underground newspaper Biuletyn Informacyjny, 30/31 July 1942, stating that the ghetto inhabitants were issued food against ration cards and only bread was available. The daily ration was 70 grams (Bartoszewski 1983: 46).

At the Siege museum, you see such a piece of bread in front of scales used at bread distribution points. Like the Siege room, the bread ration has become a symbol of the besieged city and its starving population. As such, it is also part of each and every exhibition on the siege. At the exhibition pavilion of the Piskaryov Cemetery, it forms the central object.

The Piskaryov Cemetery and Museum was the first Siege-related memorial to be opened in Leningrad. The cemetery forms the central commemoration site of the Siege in present-day St Petersburg. It was one of the main cemeteries where Siege and war victims were buried. On 20 February 1942 alone, 10,043 people were buried there in trenches. All in all, 420,000 people were buried here. The Cemetery was opened as a commemoration site on 9 May $1960 . .^{12}$

The memorial site consists of the Cemetery, that visitors enter through two pavilions which hold the permanent Siege exhibition. The visitor approaches the eternal flame. At the end of the 300-metre long central cemetery alley is a commemoration wall with plaques and inscriptions and the six-metre high bronze sculpture Mother Homeland (Mat Rodina) by the sculptors V. V. Isaev and R. K. Taurit. The memorial wall is adorned with six reliefs depicting the heroism of the citizens and the city defenders: factory workers, home guard members calling for battle. The aim of the exhibition in the pavilion is, quoting the Piskaryov memorial homepage:

to show the criminal plans of Hitler's command to destroy Leningrad, the hard life of the citizens during the 900 days of the siege, their courage, heroism, persistence and the victory over the enemy, the defeat of the German fascist armies at Leningrad. The Exhibition consists [...] mostly of documentary photographs. 


\begin{abstract}
Экспозиция должна была отражать преступные планы гитлеровского командования по уничтожению Ленинграда, тяжёлые условия жизни ленинградцев в 900-дневную блокаду города, их мужество, героизм, стойкость, победу над врагом, разгром немецко-фашистских войск под Ленинградом. [...] основное в экспозиции - документальные фотографии. ${ }^{13}$
\end{abstract}

The lights are dimmed, the atmosphere is ceremonial. The photographs show the hardships of Siege life: people queuing for water in the street, a man nibbling on a small piece of bread, people drawing their dead on sledges to collection points or cemeteries. The setting resembles a temple. This is also an effect of the architecture. A museum guidebook from 1982 describes the entrance to the cemetery as flanked by two propylaea-pavilions with marble inscription friezes that pledge eternal memory and gratefulness to the Siege heroes (Mushtukov and Tikhonov 1982: 89-90).

In the exhibition hall, ceiling is light blue, the centre of the room is crowned by a circle on which golden letters form the words "Glory to those who gave their lives for the hero city of Leningrad" (slava otdavshim zhizn za gorod-geroy Leningrad). The atmosphere of religious adoration makes the pavilion an example of the temple-type museum as analyzed by Cameron (1971) for art museums and Cristea and Radu-Bucurenci (2008) for historical museums.

\title{
Omissions
}

After the collapse of the Soviet Union, it became possible to publish what would have been edited out by Soviet censors. Historians systematically searched the archives. of organizations such as the NKVD for confiscated diaries and published them. The American historian Richard Bidlack lists some facts in his foreword to the study by Cynthia Simmons and Nina Perlina on "Women's diaries, memoirs and documentary prose" that could be written about in scholarly literature, but that are not to be found in any Siege exhibition in St. Petersburg today: That "Workers and administrators in bakeries and food stores systematically stole large quantities of food." That 2,000 people were arrested for cannibalism. That Party leaders received anonymous letters demanding the surrender of Leningrad. That the NKVD censored letters from front soldiers to their families and obliterated any comments they interpreted as defeatist. that during 1 July 1941 - 1 July 1943. 3,799 people were convicted of counterrevolutionary crimes (Bidlack 2005: xviii-xix).

The writers Daniil Granin and Ales Adamovich conducted the first oral history project on the Leningrad Siege for their Book of the Blockade (Blokadnaya kniga, 1984). The writers interviewed siege survivors and paraphrased their stories. In their study, they mainly show what people did to stay alive from one day to the next. It is the human aspect, the suffering, rather than the attribution of any heroism, that is prominent in their book. Granin and Adamovich had difficulties publishing their study. Many parts, addressing criminality, cannibalism and the helplessness of Party organs, were heavily censored in Soviet times. In the 2003 edition of the Book on the Blockade, Daniil Granin commented that in the Soviet editions, the censors did not allow references to cannibalism, misuse of ration cards and criticism of Zhdanov (19341944 Leningrad All-Union Communist Party manager). None of these aspects (cannibalism, criminality, despair) are tackled in the museum exhibitions. Susanne Brammerloh asked the curator and museum guide Dmitry Medvinsky about this. He answered that it did not make sense to tell the visitors about cannibalism and other horrors of the Siege, the museum was not the right place (Brammerloh 2011: 351)

Adamovich and Granin commented on the limits of museum exhibitions when it comes to the feeling of involvement that the reconstructions of Siege rooms aim for:

You cannot depict a siege flat in a museum, nor as a model or a panorama, since you cannot depict the frost, the sorrow, the hunger...

Блокадную квартиру нельзя изобразить ни в одном музее, ни в каком макете или панораме, так же как нельзя иобразить мороз, тоску, голод... (Adamovič and Granin 2003: 47) 
Julia Demidenko, Deputy Director for Research at the Museum of the History of St. Petersburg, criticizes the divide between the results of the historians' research and the activities of the museum responsible. She talks about existing exhibitions as well as about plans for a big Siege Museum with an experiential aspect, e.g. a room where you can feel the cold of 30 degrees Celsius below zero (Demidenko 2010: 74).

In the Siege museums and exhibitions, the visitors are encouraged to admire the people who suffered during the Siege. In an act of solidarity and identification, the visitors are supposed to accept what they are shown without doubting the dominant narrative.14

\section{Alternative narratives}

For his study of the military history of the Siege, Jörg Ganzenmüller not only analyzed decrees and reports by Party officials and organs, but also descriptions from "down below" (von unten; Ganzenmüller 2012: 12), by which he meant diaries and memoirs. This allowed him to show contradictory assessments and strategic falsifications. This approach also works in the case of the Siege museums. The official Siege narrative as presented in the museums is not without competition. During the Siege, many Leningraders kept diaries in which they documented their experiences. Some of the diaries were published in the Soviet Union, others in Western countries (USA, Federal Republic of Germany, UK and others). The end of the Soviet Union and the subsequent opening of the archives led to a wave of published Siege memories. These diaries tell a story that differs significantly from the myth of collective heroism.

Diaries are expected to report authentic, immediate experiences (Paperno 2004: 565). In Stalin's Soviet Union, people were encouraged to write diaries for other than individual purposes. The diarists should self-improve by discussing their shortcomings in their social and political struggle. As Jochen Hellbeck could show, many diaries written under Stalinism became a mixture of individual thoughts and political doctrine. Writing a personal diary was a dangerous undertaking as these documents were often exploited by secret police (Hellbeck 2006). Frontline soldiers were not allowed to keep a diary (Merridale 2004: 7). The writer Vasily Aksionov - he later emigrated to the USA - makes use of the demand of a diary to come up to the standards of a Soviet consciousness in one of his early stories, Oranges from Morokko (Apelsiny iz Marokko, 1959). In one scene, a group of young girls reads another girl's diary where she has also written down a poem. The girls like the poem, but one of them, the firstperson narrator, comments:

I said that the verses were well-rhymed but very subjective and that they did not represent our generation's attitudes.

Я сказала, что, хотя стихи и хороши по рифме, все же они узколичные и не отражают настроений нашего поколения. (Aksënov 2006, 16)

In Aksionov's text as in Hellbeck's analysis, Soviet diaries were meant to have a public character. But many diarists did not adhere to this ideological demand. In many cases Siege diaries specifically serve in Paperno's definition as representations of "a lasting trace of one's being-an effective defense against annihilation" (Paperno 2004, 563) in times of daily threats of extinction.

Almost all of the diarists mention hearing Molotov's radio speech on the 22 June, the air raids, the windows covered with paper stripes, the days that the radio, the tram service or the water supply were cut off, the heating and cooking with burzhuykas, the cutting of the food, especially the bread rations, attempts to eat other things not deemed edible before, dead bodies in neighbouring rooms or in the street, people taking the dead to the cemeteries on child sledges.

The diaries that were published before the end of the Soviet Union showed the suffering of the population, but also the hope and certainty that it would all come to a good end, that there was a purpose to the suffering. A typical example is Vera Inber's diary Almost Three Years: Leningrad Diary (Pochti tri goda: Leningradskii dnevnik), published in 1946. She does not ignore the fact that not all Leningraders were heroic and that small and large crimes occurred. But in her description, the irresistible quality of Stalin's voice in his radio speech on 
11 October 1941 gave consolation to everybody. Praising Stalin was a necessary convention of the time. It is interesting, though, to see the recorded reactions to such publications. The praise of Stalin and assurances of permanent hope stood in contrast to the experiences of the Leningrad citizens. In 2010, the memoirs of Vladislav Glinka, written in 1979, were published. Glinka, who had worked at the Hermitage Museum, writes about his reasons for noting down his own memories: because everything else he had read was "criminally wrong" (prestupno Izhivo), often told from the perspective of privileged people, generals, their wives. He especially singles out the wife of the Director of the medical institute, Vera Inber, who in his opinion wrote, in order to be published, about heroism, but remained silent about well known occurrences such as theft, speculation with provision cards and the black market. Glinka is offended by this "canon of heroism" (kanon geroizma; Glinka 2010: 32).

Many critical diaries were published in the West. This practice continued after 1991. Cynthia Simmons and Nina Perlina, in their study, published for the first time in English translation excerpts from Anna Petrovna Ostroumova-Lebedeva's diary that would never have passed a Soviet censor, among other things for her allegations that state officials stole food. Her diary entry for 22nd May 1942 reads:

Anastasia Osipovna came to see me. She had recently been to the public baths and was completely astounded by the large number of well-fed Rubenesque young women with radiant bodies and glowing physiognomies. They are all workers in bakeries, cooperatives, soup kitchens, and children's centers. (Simmons and Perlova 2005: 32)

The Saint Petersburg Institute of History of the Russian Academy of Sciences has conducted several projects and as a result has published compilations of diaries and also single diaries found in several archives. In 2008, the group of editors published the compilation Man during the Siege (Chelovek v blockade). One of the diaries included is that of Alexander Gryaznov. On 4 October 1941, he recorded an ugly scene he had witnessed in a canteen. A lightly wounded soldier demanded to be served without being registered; the woman working there told him to ask the Director; then this "defender of the fatherland" said: "You are not being bombed enough. The bombardment should be stronger and more often." (Malo vas bombjat, nado, shtob posilney da pochashche ; Koval'čuk et al 2008: 27-28)

In 2004, Bernev and Černov published a collection of diaries they had found in secret service archives. One is the diary of the teacher Aleksey Vinokurov. He had been arrested by the NKVD on 12 February 1943. His diary had been confiscated and was used as evidence during the trial where he was found guilty of counterrevolutionary agitation. He was shot on 19 March 1943. In 1999, he was rehabilitated. The examining magistrate had underlined certain passages in the diary, for example the entry for 14 March 1942 about the body of a woman that had been hacked to pieces. Vinokurov commented that this probably proved the rumors about cannibalism. These comments were interpreted as defeatism, to be punished by death.

\title{
Conclusion
}

Dmitry Likhachov, a philologist who survived both the Gulag and the Siege, wrote in his memoirs the following about Siege life in Leningrad:

\begin{abstract}
When they were hungry the people showed themselves, became naked, freed themselves of everything superfluous: some proved to be remarkable, incomparable heroes, others criminals, villains, murderers, cannibals. There was no middle way. Everything was genuine.
\end{abstract}

В голод люди показали себя, обнажились, освободились от всяческой мишуры: одни оказались замечательные, беспримерные герои, другие - злодеи, мерзавцы, убийцы, людоеды. Середины не было. Все было настоящее. (Lichačë 1995: 341-342)

While the diaries and memoirs and also literary works of art as Lidiya Ginzburg's Blockade Diary (Zapiski blokadnogo cheloveka, published 1984) show the extremes, the museums stick to the heroic narrative. 
Susanne Brammerloh, in talking about the first Leningrad Siege Museum, opened in 1944 , states that it concentrated on the weaponry, not civil suffering and that this was necessary due to the ruling ideology and its rule that one could only show the heroic part of the defense of Leningrad (Brammerloh 2011: 347). The heroic myth of the Soviet fighter has been the target of research e.g. by the historian Sabine Arnold. In relation to the battle of Stalingrad, she comes to the conclusion that so-called heroic deeds more often than not were in fact reactions to extreme crisis:

The heroes were hostages of the army leadership, their deeds the expression of deepest despair.

Die Helden waren Geiseln der Armeeführung, ihre Taten Ausdruck höchster Verzweiflung (Arnold 1998: 396).

The Siege museums follow the interpretive pattern of collective heroism, thus joining the depiction in film, documentaries and the social praxis and rituals of celebration and commemoration and the emotional connotations they arouse.

The reinforcement of the heroic paradigm is coherent with the Russian instrumentalization of Russian and Soviet history for state purposes. Elizabeth Wood shows that Vladimir Putin (born in 1952) visits places and institutions linked to the war and also uses new or reinstated symbols like the St George's ribbon to present himself as a manly and powerful ruler.15 The nation as a holy institution is identified with the victory in 1945 as its greatest achievement. War and victory in turn are identified personally with Vladimir Putin. One of his methods is Putin's often-repeated reference to his family's suffering during the Leningrad Siege. In this argument, as a "mythic event" (Wood 2011, 177), the War does not have to be analyzed and critical aspects (Hitler-Stalin pact, lack of war preparation etc.) do not have to be considered. Instead we are encouraged to adopt an emotional admiration for those who suffered, an emotion that Putin can exploit through his family association with the siege. In so doing he can be understood to have exploited a form of "emotional contagion" (emotionale Ansteckung) (Scheler 1923: 25), made easier by the failure of the museums to question the notion of heroism and offer more nuanced accounts of the suffering of civilians.

Wood's findings are consistent with the attitude in the Siege museums' exhibitions: their visitors are invited to contemplate, admire and empathize, but not to develop any doubt in Leningrad's collective heroism. Every detail that could raise questions is left out.

Daniil Granin was quoted in 2014 by the online news agency Rosbalt.ru with two comments on heroism and the Siege. He said that the Museum of the Siege and the Defense of Leningrad should show the whole truth and not only talk about the heroes. In seeming contradiction to this statement, he then said that the Siege had only one hero, or rather heroine: Olga Berggolts. 16

The poet Olga Berggolts featured prominently during the Siege in radio programmes where she read her new texts. A poem of Berggolts' was commissioned for the opening of the Piskaryov cemetery memorial. The poem is engraved in a stele on the cemetery. The last line has become the best known quotation in connection with the Siege: "No one is forgotten and nothing is forgotten" (Nikto ne zapby i nishto ne zabyto). Granin knows that one of Berggolts' most famous poems starts with the lines "I have never been a hero" (Ya nikogda geroyem ne byla; Berggol'c 1973: 56).

Granin's reference challenges the instrumentalization of "blokadniki" (Siege survivors) and Siege victims as heroes. If they were not heroes, if they are not role models never to be reached, they can be seen as helpless victims.

Commemorating the Great Patriotic War is generally presented as patriotic duty, aiming at raising patriotic feelings. Film director Nikita Mikhalkov has announced plans of building a fun and theme park called Citatel where children are to be made familiar with the heroic aspects of Russia's history17 (Druzhinina 2016; Holm 2016b). Warning voices like Granin's are rare in Russia today.

Received: 1 January 2016

Finally accepted: 1 November 2016 


\section{Notes}

1 All translations from German or Russian, if not marked differently, are by the author, Yvonne PörzgenPörzgen.

2 The Museum of Feelings, homepage. https://www.themuseumoffeelings.com/ accessed 29 September 2016.

3 Bol'šaja Sovetskaya Ėnciklopedia, ${ }^{\text {rd }}$ edition 1969-1978, 'Geroism'. http://bse.sci-lib.com/ article009855.html, accessed 29 September 2016.

42011 Muchina, Lena, “...Sochrani moju pečal'nuju istorju...”. Blokadnyj dnevnik Leny Muchinoj.

2010 Berggol'c, Ol'ga; Sokolovskaja, Natalija (ed), Ol'ga. Zapretnyj dnevnik. Dnevniki, pis'ma, proza, izbrannye stichotvorenija i poèmy Ol'gi Berggol'c.

2010 Glinka, Vladislav Michajlovich, Vospominanija o blokade.

2010 Koval'čuk, V. M., Rupasov, A. I.; Čistikov, A. N. (eds) “Ja ne sdamsja do poslednego...”: Zapiski iz blokadnogo Leningrada.

2009 Koval'čuk, V. M.; Rupasov, A. I.; Čistikov, A. N. (eds), "Doživem li my to tišiny?" Zapiski iz blokadnogo Leningrada.

2008 V. M. Koval'čuk; Rupasov, A. I.; Čistikov, A. N. (eds), Čelovek v blockade. Novye svidetel'stva.

2006 Loskutova, Marina V. (ed), Pamjat' o blokade: svidetel'stva očevidcev i istoričesoe soznanie obščestva.

2008 Šmelev, O., Pamjat' blokadnogo mal'čiški.

2005 Vinogradov, A. V., Bitva za Leningrad v sud'bach žitelej goroda i oblasti. Vospominanija zaščitnikov ižitelej blokadnogo goroda i okkupirovannych territorij. Posvjaščaetsja 60-letiku Velikoj Pobedy.

2005 Lebedev, Jurij M., Po obe storony blokadnogo kol'ca.

1998-2006 35 tomov knigi pamjati „Blokada”.

1998 Daev, Vladimir Grigor'evič: S distancii poluveka. Očerki blokadnogo Leningrada.

1998 Boldyrev, Aleksandr Nikolaevič: Osadnaja Zapis'. Blokadnyj dnevnik.

1993 Gorškov, Nikolaj Pavlovič: Siloju sveta v polsveči. Blokadnyj dnevnik, najdennyj čerez 50 let $v$ sekretnych archivach KGB.

1989 Magračev, Lazar' Efimovič: Reportaž iz blokady.

1981 Kočina, Elena, Dnevnik.

5 or a more detailed overview on the development of Siege research, see Zemskov-Züge 2012.

6 Velikaja Otečestvennaja vojna, 'Goroda-geroi'. http://warsite.ru/index/goroda_geroi/0-57, accessed 29 September 2016.

7 Bol'šaja Sovetskaya Ėnciklopedia, $3^{\text {rd }}$ edition 1969-1978, 'Goroda-geroi'. http://bse.sci-lib. com/article011906.html, accessed 29 September 2016. 
8 Elizabeth Wood additionally mentions Kirill Nabutov's 2004 film Blokada Leningrada, and the 2005 NTV TV-production Rozhdenie Pobedy (Birth of the Victory). In both films, Vladimir Putin's father features prominently as Soviet soldier whose wife and son (V. Putin's older brother) suffer in the besieged City. Both films, Wood states, served to install Putin as man of the people and deserving representative. See Wood 2011: 187.

9 L. M. Markova, 'Blokadnaja chronika Tani Savičevoj'. http://spb-family.ru/history/history 15.

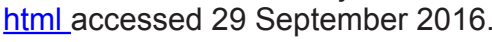

10 The smallest bread ration was already part of the wartime Siege exhibition and the postwar museum on the Heroic defence of Leningrad. See Zemskov-Züge 2012: 253.

11 Stephen Maddox, 'Healing the Wounds: Commemorations, Myths and the Restoration of Leningrad's Imperial Heritage, 1941-1950', dissertation. https://tspace.library.utoronto. ca/bitstream/1807/16769/1/Maddox_Steven_200811_PhD thesis.pdf , accessed 29 September 2016.

12 Piskarëvskoe memorial'noe kladbišče, 'O blockade: istoria'. http://pmemorial.ru/blockade/ history accessed 29 Septemer 2016.

13 Piskarëvskoe memorial'noe kladbišče, 'O memoriale'. http://pmemorial.ru/memorial accessed 29 September 2016.

14 Whether the intended effect is achieved remains to be shown e.g. by interviews with visitors.

15 The St George's ribbon was part of a Tsarist military decoration. During the Second World War, it became the badge of the Soviet Guards. Several Soviet orders afterwards featured the ribbon. From 2005 onwards, the ribbon is distributed by young people ahead of Victory Day all over Russia. Since 2014, pro-Russian separatists in Ukraine have taken over the St George's ribbon as their symbol. This latest development finally identified the ribbon which was first introduced as an emblem of the 60th anniversary of the end of the Great Patriotic War into a symbol of pro-Putin state support. See Alexander Kim, 'St. George's Ribbons and Their Dubious Symbolism in Post-Soviet Central Asia', Eurasia Daily Monitor, volume 12, issue 86, May 7 2015. https://jamestown.org/program/st-georges-ribbons-andtheir-dubious-symbolism-in-post-soviet-central-asial accessed 29 September 2016.

16 Rosbalt.ru, 'Granin: U blokady odin geroj - Ol'ga Berggol'c'. http://www.rosbalt.rul piter/2014/02/04/1229282.html accessed 29 September 2016.

17 Irina Družinina, 'Nikita Michalkov rasskazal o ,Tsitateli“ v Nižegorodskoj oblasti', 17 June 2016 http://nn-now.ru/novosti/nikita-mihalkov-rasskazal-o-tsitadeli-v-nizhegorodskoyoblasti/ accessed 29 September 2016.

\section{References}

Adamovič, A. and Granin, D. (2005) Blokadnaja kniga, Moskva: Terra - Knižnyj Klub.

Aksënov, V. (2006) Apel'siny iz Marokko, Moskva: Ėksmo.

Arnold, S. R. (1998) Stalingrad im sowjetischen Gedächtnis. Kriegserinnerung und Geschichtsbild im totalitären Staat, Bochum: Projekt Verlag.

Bartoszewski, W. (1983) Das Warschauer Ghetto - wie es wirklich war. Zeugenbericht eines Christen, Frankfurt am Main: Fischer Taschenbuch Verlag.

Berggol'c, O. F. (1973) Sobranie sočinenij, 2, Stichotvorenija. Govorit Leningrad. Vernost, Leningrad: Chudožestvennaja Literatura. 
Bernev, S. (ed) (2007) Blokadnye dnevniki i dokumenty, $2^{\text {nd }}$ improved edition, SanktPeterburg: Evropejskij Dom.

Bidlack, R. (2002 / paperback 2005) 'Foreword: Historical Backgrounds to the Siege of Leningrad' in Cynthia Simmons and Nina Perlina (eds) Writing the Siege of Leningrad: Women's Diaries, Memoirs, and Documentary Prose, ix-xxvi, Pittsburgh: University of Pittsburgh Press.

Bogumił, Z., Senina, M., Wawrzyniak, J., Buchen, T. and Ganzer, Ch. (2015) The Enemy on Display: The Second World War in Eastern European Museums, New York, Oxford: Berghahn.

Brammerloh, S. (2011) 'Brüchige Erinnerung. Die Geschichte des Blockademuseums', Osteuropa, 61 (8-9) 343-351.

Cameron, D. (1971) 'The Museum: A Temple or the Forum', Curator: The Museum Journal, 14 (1) $7-74$.

Ciompi, L. and Endert, E. (2011) Gefühle machen Geschichte. Die Wirkung kollektiver Emotionen - von Hitler bis Obama, Vandenhoeck \& Ruprecht: Göttingen.

Cristea, G. and Radu-Bucurenci, S. (2007) 'Raising the Cross: Exorcising Romania's Communist Past in Museums, Memorials and Monuments', in Oksana Sarkisova and Péter Apor (eds) Past for the Eyes: East European Representations of Communism in Cinema and Museums after 1989, 275-305, Budapest: Central European University Press.

Damasio, A. (2000) The Feeling of What Happens: Body and Emotion in the Making of Consciousness, London: Heinemann.

Demidenko, J. (2010) ‘Erinnerung an die Blockade: ein Schritt vor, zwei Schritte zurück', in Margot Blank(ed) Chandogin, Kriegsfotos aus Karelien und Leningrad 1939-1944. Katalog zur Ausstellung im Deutsch-Russischen Museum Berlin-Karlshorst, 5. November 2010 - 6. Februar 2011, 58-75, Bönen: Druckverlag Kettler.

Dzeniskevič, A. (1998) Blokada i politika. Oborona Leningrada v političeskoj konjunkture, Sankt-Peterburg: Nestor.

Fieseler, B. and Ganzenmüller, J. (eds) (2010) Kriegsbilder: Mediale Repräsentationen des 'Großen Vaterländischen Krieges', Essen: Klartext-Verlag.

Frevert, U. (2010) 'Vom heroischen Menschen zum "Helden des Alltags"“, in LWLIndustriemuseum (ed) Helden. Von der Sehnsucht nach dem Besonderen. Katalog zur Ausstellung im LWL-Industriemuseum Henrichshütte Hattingen, 12.3.31.10.2010, 12-19, Essen: Klartext-Verlag.

Ginzburg, L. (1989) 'Zapiski blokadnogo čekoveka', in Lidija Ginzburg Čelovek za pis'mennym stolom: Ėsse. Iz vospominanij. Četyre povestvovanija, 517-578, Leningrad: Sovetskij pisatel.

Ganzenmüller, J. (2005) Das belagerte Leningrad 1941-1944. Die Stadt in den Strategien von Angreifern und Verteidigern, Potsdam, Paderborn, München, Wien, Zürich: Schöningh.

Glinka, V. M. (2010) Vospominanija o blokade, Sankt-Peterburg: Limbus Press.

Immer, N. and van Marwyck, M. (eds) (2013) Ästhetischer Heroismus. Konzeptionelle und figurative Paradigmen des Helden, Bielefeld: transcript. 
Hellbeck, J. (2006) Revolution on My Mind. Writing a Diary Under Stalin, Cambridge: Harvard University Press.

Holm, K. (2016a) 'Emotionsmusem in Sankt Petersburg eröffnet', in Frankfurter Allgemeine Zeitung, 11 May, 9.

(2016b) 'Weltkrieg als Ferienspaß. Nikita Michalkow baut patriotischen Themenpark', in Frankfurter Allgemeine Zeitung, 22 June, 12.

Inber, V. M. (1968), Počti tri goda. Leningradskij dnevnik, Moskva: Sovetskaja Rossija.

Jäniche, G. and Leetz, A. (eds) (1992) Blockade. Leningrad 1941-1944. Dokumente und Essays von Russen und Deutschen, Reinbek bei Hamburg: Rowohlt.

Jauß, H. R. (1974) 'Levels of Identification of Hero and Audience', New Literary History, 5 (2) 283-317.

Kamiński, Ł. (2016) 'Finger weg von unseren Helden', in Frankfurter Allgemeine Zeitung, 15 April, 9.

Kirschenbaum, L. (2006) The Legacy of the Siege of Leningrad, 1941-1995: Myth, Memories, and Monuments, New York: Cambridge University Press.

(2002) 'Innocent Victims and Heroic Defenders: Children and the Siege of Leningrad', in James Marten (ed) Children and War: A Historical Anthology, New York and London: New York University Press.

Koval'čuk, V. (2003) 'Velikaja Otečestvennaja Vojna', in Valentin Kovalčuk (ed) SanktPeterburg. 300 let istorii, 532-600, Sankt-Peterburg: Nauka.

Koval'čuk, V. M., Rupasov, A. I. and Čistikov, A. N. (eds) (2008) Čelovek v blokade. Novye svidetel'stva, Sankt-Peterburg: Rossijskaja Akademija Nauk, Sankt-Peterburgskij Institut Istorii.

Lichačev, D. (1995) Vospominanija, Sankt-Peterburg: Logos.

Loskutova, M. V. (ed) (2006): Pamjat' o blokade. Svidetel'stva očevidcev i istoričeskoe soznanie obščestva, Moskva: Novoe izdatel'stvo.

Malvern, S. (2000) 'War, Memory and Museums: Art and Artefact in the Imperial War Museum', History Workshop Journal, spring (49) 175-201.

Melnikow, M. (2011) 'Abbild ohne Original. Die Blockade Leningrads im Fernsehen', Osteuropa, 61 (8-9) 329-341.

Merridale, C. (2005) Ivan‘s War, the Red Army 1939-1945, London: Faber and Faber.

Müller, A. W. and Reisenzein, R. (2013) Emotionen - Natur und Funktion, Göttingen: Vandenhoeck \& Ruprecht.

Münkler, H. (2007) 'Heroische und postheroische Gesellschaften', Merkur, deutsche Zeitschrift für europäisches Denken, 61 (700), 742-752.

Mushtukov, V. and Tikhonov, L. (1982) Piskarevskoye Memorial Cemetery, translated from the Russian by Barry Jones, Moscow: Progress Publishers.

Paperno, I. (2004) 'What Can Be Done with Diaries?' Russian Review, 63 (4) 561-573. 
Pavlov, D. V. (1958) Leningrad v blokade, Moskva: Voennoe izdatel'stvo MO SSSR. Rambow, A. (1995) Überleben mit Worten. Literatur und Ideologie während der Blockade von Leningrad 1941-1944, Berlin: Verlag Arno Spitz.

Reid, A. (2011) Leningrad: The Epic Siege of World War II: 1941-1944, London: Bloomsbury Publishing.

Scheler, M. (1923) Wesen und Formen der Sympathie. Neuausgabe von Phänomenologie d. Sympathiegefühle von 1913. 2. Auflage, Bonn: F. Cohen.

Scherrer, J. (2002) “'Sehnsucht nach Geschichte”. Der Umgang mit Vergangenheit im postsowjetischen Russland', in Christoph Conrad and Sebastian Conrad (eds) Geschichte schreiben. Geschichtswissenschaft im internationalen Vergleich, Göttingen: Vandenhoeck \& Ruprecht, 165-206.

Schilling, R. (2002) 'Kriegshelden'. Deutungsmuster heroischer Männlichkeit in Deutschland 1813-1945, Paderborn: Schöningh.

Schnabel, U. (1995) 'Große Koalition des Mitgefühls', in Die Zeit, 10 September, 33-34.

Schoder, A. (2014) Die Vermittlung des Unbegreiflichen: Darstellung des Holocaust im Museum, Frankfurt am Main: Campus.

Simmons, C. and Perlina, N. (eds) (2005) Writing the siege of Leningrad: Women's Diaries, Memoirs, and Documentary Prose, Pittsburgh: University of Pittsburgh Press.

Šiškin, A. A. and Medvinskij, D. Ju. (2014) Gosudarstvennyj memorial'nyj muzej oborony i blokady Leningrada. Putevoditel', Sankt-Peterburg.

Šiškin, M. A. (ed) (1996) Universitet v blokadnom i osaždennom Leningrade 1941-1944, Sankt-Peterburg: Gippokrat

Suris, B. D. (1993) Bol'še, čem vospominanija: Pis'ma leningradskich chudožnikov, SanktPeterburg: Kul't-Inform-Press.

Voss, J. (2016) 'Mit dabei ist auch dagegen. Endlich Altmeister: Eine riesige Ausstellung im Städel Museum Frankfurt zeigt die "Helden" von Georg Baselitz. Aber was für Helden sind das genau?', in Frankfurter Allgemeine Zeitung, 30 June, 11.

Wood, E. A. (2011) 'Performing Memory: Vladimir Putin and the Celebration of World War II in Russia', The Soviet and Post-Soviet Review, 38 (2) 172-200.

Zemskov-Züge, A: (2011) 'Helden um jeden Preis. Leningrader Kriegsgeschichte(n)', Osteuropa, 61 (8-9) 135-153.

(2012) Zwischen politischen Strukturen und Zeitzeugenschaft: Geschichtsbilder zur Belagerung Leningrads in der Sowjetunion, 1943-1953, Göttingen: V\&R unipress.

*Dr. Yvonne Pörzgen ( ${ }^{*} 1977$ ) is a research assistant at the Institute for Eastern and Central European Studies at the University of Bremen. From 2016 to 2018, Yvonne Poerzgen is a DAAD lecturer at the State University of Ulyanovsk (Russian Federation). She earned both her MA and $\mathrm{PhD}$ at the University of Bamberg in Slavic philology and English studies. In her PhD thesis she analyzes the function of drugs in Polish and Russian contemporary literatures. In 2012, she was awarded a research grant from the German Poland Institute in Darmstadt and a DAAD short-term teaching award at the Pedagogical University Čita (Russian Federation) in 2011. Currently, she is working on a post-doc project on the implementation of the interdisciplinary free-will discourse in the interpretation of Slavic literatures. 
Contact address:

Dr Yvonne Pörzgen

Flensburger Strasse 57

D-28219 Bremen

E-Mail: poerzgen@uni-bremen.de 